ISSN: 2302-8556

E-Jurnal Akuntansi Universitas Udayana

Vol.22.3. Maret (2018): 2088-2116

DOI: https://doi.org/10.24843/EJA.2018.v22.i03.p17

\title{
Pengaruh Profitabilitas, Leverage, dan Kepemilikan Institusional pada Tax Avoidance
}

\section{Putu Winning Arianandini ${ }^{1}$ I Wayan Ramantha ${ }^{2}$}

\author{
${ }^{1}$ Fakultas Ekonomi dan Bisnis Universitas Udayana (Unud), Bali, Indonesia \\ email: winning.arnd24@gmail.com/Telp: +6281239013999 \\ ${ }^{2}$ Fakultas Ekonomi dan Bisnis Universitas Udayana (Unud), Bali, Indonesia
}

\begin{abstract}
ABSTRAK
Perusahaan berusaha menekan biaya pajaknya demi mendapatkan laba yang lebih tinggi. Penelitian ini bertujuan menguji pengaruh profitabilitas, leverage, dan kepemilikan institusional terhadap penghindaran pajak. Penelitian ini difokuskan pada perusahaan manufaktur yang terdaftar di Bursa Efek Indonesia (BEI) periode tahun 2012-2016 dengan populasi 157 perusahaan. Penentuan jumlah sampel menggunakan metode purposive sampling, sehingga diperoleh sampel sabanyak 39 perusahaan manufaktur. Pengujian hipotesis dilakukan dengan teknik analisis regresi linear berganda. Metode pengujian hipotesis menggunakan tingkat signifikansi sebesar 5\%. Penelitian ini memperoleh hasil pertama, variabel profitabilitas berpengaruh negatif pada penghindaran pajak. Hasil kedua, variabel leverage tidak berpengaruh pada penghindaran pajak. Hasil ketiga, variabel kepemilikan institusional tidak berpengaruh pada penghindaran pajak.
\end{abstract}

Kata Kunci : Profitabilitas, leverage, kepemilikan institusional, tax avoidance.

\section{ABSTRACT}

Companies are trying to lower their tax costs in order to earn a higher profit. This study aims to examine the effect of profitability, leverage, and institutional ownership of tax avoidance. This study focused on manufacturing companies listed on the Indonesia Stock Exchange (IDX) period 2012-2016 with a population of 157 companies. Determination of the number of samples using purposive sampling method, samples obtained by 39 manufacturing companies. Hypothesis testing is done by multiple linear regression analysis technique. Hypothesis testing method using significance level of 5\%. This study obtained the first result, the profitability variable negatively affect the tax avoidance. The second result, on the leverage variables has no effect on tax avoidance. The third result, the institutional ownership variable has no effect on tax avoidance.

Keywords: Profitability, leverage, institutional ownership, tax avoidance.

\section{PENDAHULUAN}

Pajak merupakan sumber pendapatan Negara terbesar bila dibandingkan dengan sumber pendapatan lainnya di Indonesia. Pajak dapat berperan dalam mendukung pembangunan suatu Negara. Dengan retribusi dan pajak, pemerintah mampu 
mendanai pembangunan-pembangunan daerah guna menciptakan kesejahteraan masyarakat. Definisi pajak menurut Undang-Undang Nomor 16 tahun 2009 tentang Ketentuan Umum dan Tata Cara Perpajakan pada Pasal 1 ayat 1 berbunyi pajak adalah kontribusi wajib kepada negara yang terutang oleh orang pribadi atau badan yang bersifat memaksa berdasarkan Undang-Undang, dengan tidak mendapatkan imbalan secara langsung dan digunakan untuk keperluan negara bagi sebesarbesarnya kemakmuran rakyat.

Pada tahun 1984 telah terjadi peristiwa tax reform dimana mengakibatkan perubahan pada sistem perpajakan di Indonesia yang awalnya adalah official assessment system berubah menjadi self assessment system. Official assessment system adalah sistem pemungutan pajak yang memberikan tanggung jawab sepenuhnya kepada pemerintah dalam melakukan pemungutan pajak, sedangkan self assessment system adalah sistem pemungutan pajak yang memberikan wewenang dan kepercayaan kepada wajib pajak orang pribadi maupun badan untuk menghitung, memperhitungkan, menyetorkan, dan melaporkan pajak yang terutang kepada Negara (Hutagaol, 2013). Diharapkan dengan adanya perubahan sistem pemungutan pajak menjadi self assessment system dapat membuat wajib pajak mematuhi kewajiban perpajakannya secara sukarela sesuai dengan peraturan perpajakan yang berlaku.

Pemungutan pajak bukan merupakan hal yang mudah untuk diterapkan. Bagi negara, pajak merupakan sumber pendapatan. Namun hal tersebut berbeda dengan perusahaan. Bagi perusahaan pajak adalah beban yang akan mengurangi laba bersih. 
Dalam pelaksanaannya terdapat perbedaan kepentingan antara wajib pajak dengan pemerintah. Perusahaan berusaha untuk membayar pajak sekecil mungkin karena dengan membayar pajak berarti mengurangi kemampuan ekonomis perusahaan (Suandy, 2008). Kondisi itulah yang menyebabkan banyak perusahaan berusaha mencari cara untuk meminimalkan beban pajak . Meminimalkan beban pajak dapat dilakukan dengan berbagai cara, mulai dari yang masih berada dalam bingkai peraturan perpajakan sampai dengan yang melanggar peraturan perpajakan (Sari, 2014). Meminimalkan kewajiban pajak yang tidak melanggar Undang-Undang biasa disebut dengan istilah tax avoidance.

Tax avoidance adalah cara untuk menghindari pembayaran pajak secara legal yang dilakukan oleh Wajib Pajak dengan cara mengurangi jumlah pajak terutangnya tanpa melanggar peraturan perpajakan atau dengan istilah lainnya mencari kelemahan peraturan (Hutagaol, 2007). Menurut Lim (2011) mendefinisikan tax avoidance sebagai penghematan pajak yang timbul dengan memanfaatkan ketentuan perpajakan yang dilakukan secara legal untuk meminimalkan kewajiban pajak. Tindakan penghindaran pajak akan mengurangi kas negara atau mempengaruhi penerimaan negara dalam Anggaran Pendapatan dan Belanja Negara (APBN). Penerimaan pajak di Indonesia sudah direncanakan sedemikian rupa agar mencapai target yang diinginkan sesuai dengan anggaran pendapatan di Anggaran Pendapatan dan Belanja Negara (APBN). 
Banyak perusahaan lebih mementingkan untuk memaksimalkan laba sebesarbesarnya, sehingga banyak perusahaan yang menerapkan efisiensi ketat terhadap biaya pajak (Utami, 2013). Namun sayangnya tindakan ini biasanya tidak disertai dengan pertimbangan kemungkinan bahwa biaya pajak tersebut akan ditagihkan melalui pemeriksaan pajak. Tindakan agresif pajak juga dapat memicu sanksi atau pinalti dari pejabat pajak dan juga dapat berakibat terjadinya penurunan harga saham perusahaan. Penurunan harga saham tersebut dapat terjadi disebabkan karena adanya pemegang saham lain yang menyadari bahwa tindakan agresif pajak yang dilakukan oleh manajer bertujuan untuk ekstraksi sewa (Desai dan Dharmapala, 2006). Hal ini semakin meningkatkan resiko bagi perusahaan yang tentunya akan berpengaruh pada kelancaran bisnisnya.

Indonesia pun tidak luput dari adanya praktik penghindaran pajak. Pada tahun 2005 terdapat 750 perusahaan Penanaman Modal Asing (PMA) yang ditengarai melakukan penghindaran pajak dengan melaporkan rugi dalam waktu 5 tahun berturut-turut dan tidak membayar pajak (Bappenas, 2005 dalam Prakosa, 2014). Berdasarkan data pajak yang di sampaikan oleh Dirjen Pajak pada tahun 2012 ada 4.000 perusahaan PMA yang melaporkan nihil nilai pajaknya, perusahaan tersebut diketahui ada yang mengalami kerugian selama 7 tahun berturut-turut. Perusahaan tersebut umumnya bergerak pada sektor manufaktur dan pengolahan bahan baku (DJP, 2013 dalam Prakosa, 2014). 
ISSN: 2302-8556

E-Jurnal Akuntansi Universitas Udayana

Vol.22.3. Maret (2018): 2088-2116

Di Indonesia sendiri, permasalah mengenai praktik penghindaran pajak ini sudah sangat sering terjadi. Global Financial Integrity (GFI) mencatat aliran dana haram atau illicit yang dihasilkan dari penghindaran pajak dan aktivitas ilegal di Indonesia dan dikirim ke luar negeri mencapai US\$6,6 triliun sepanjang satu dekade terakhir. Dalam laporan GFI tersebut, Indonesia menduduki peringkat ketujuh terbesar sebagai negara asal dana illicit di seluruh dunia. Adapun praktik ilegal yang lazim digunakan untuk melakukan penghindaran pajak adalah transfer pricing. Hal tersebut dicurigai karena ditemukan sekitar 4.000 perusahaan multinasional yang beroperasi selama belasan dan puluhan tahun, terus melaporkan kerugian tapi tetap berekspansi. Skema transfer pricing sendiri dikenal cukup ampuh untuk mengakali tarif pajak dengan 'mengalihkan' pendapatan dan laba perusahaan di suatu negara kepada induk perusahaan di negara lain yang memiliki tarif pajak rendah (sumber:http://financial.bisnis.com, Rabu,19 Juli 2017)

Terdapat beberapa faktor yang mempengaruhi manajemen untuk melakukan penghindaran pajak (tax avoidance). Dalam penelitian Maharani (2014) menyatakan bahwa terdapat beberapa faktor yang mempengaruhi manajemen melakukan praktik penghindaran pajak yaitu corporate governance, profitabilitas, dan karakteristik eksekutif. Dalam penelitian tersebut menunjukkan hasil bahwa profitabilitas berpengaruh negatif terhadap praktik penghindaran pajak. Hal ini bertentangan dengan penelitian yang dilakukan oleh Utami (2013) yang menyatakan bahwa profitabilitas tidak berpengaruh terhadap penghindaran pajak. Kemudian dalam 
penelitian Swingly (2015) menyatakan karakter eksekutif, komite audit, ukuran perusahaan, leverage, dan sales growth merupakan faktor yang mempengaruhi praktik penghindaran pajak. Dimana pada penelitian tersebut menunjukkan hasil bahwa leverage berpengaruh terhadap penghindaran pajak. Sedangkan pada penelitian yang dilakukan oleh Agusti (2014) menyatakan bahwa leverage tidak berpengaruh terhadap praktik penghindaran pajak.

Kemudian Sari (2014) dalam penelitiannya menyebutkan ada beberapa faktor yang mempengaruhi penghindaran pajak, yaitu komisaris independen, komite audit, ukuran perusahaan, kompensasi rugi fiskal, dan struktur kepemilikan institusional. Dalam penelitiannya tersebut menyatakan bahwa kepemilikan institusional memiliki pengaruh terhadap terjadinya penghindaran pajak. Hal ini bertentangan dengan penelitian yang dilakukan oleh Diantari (2016) yang menyatakan bahwa kepemilikan institusional tidak memiliki pengaruh terhadap praktik penghindaran pajak. Dari faktor-faktor yang mempengaruhi penghindaran pajak tersebut, dalam penelitian ini peneliti memilih menggunakan profitabilitas, leverage, dan kepemilikan institusional sebagai variabel yang mempengaruhi penghindaran pajak.

Profitabilitas adalah suatu ukuran dalam menilai kinerja suatu perusahaan. Profitabilitas menggambarkan kemampuan perusahaan dalam memanfaatkan asetnya secara efisien dalam menghasilkan laba perusahaan dari pengelolaan aktiva yang dikenal dengan Return On Asset (ROA). ROA yang positif menunjukkan bahwa dari total aktiva yang dipergunakan untuk beroperasi perusahaan mampu memberikan laba 
ISSN: 2302-8556

E-Jurnal Akuntansi Universitas Udayana

Vol.22.3. Maret (2018): 2088-2116

bagi perusahaan. ROA dinyatakan dalam prosentase, semakin tinggi nilai ROA maka akan semakin baik kinerja perusahaan tersebut. Laba merupakan dasar dari pengenaan pajak. Semakin tinggi laba suatu perusahaan maka beban pajak yang dibayarkan juga semakin tinggi.

Selain hal di atas, adanya indikasi perusahaan dalam melakukan penghindaran pajak dapat dilihat dari kebijakan pendanaan yang diambil perusahaan. Salah satu kebijakan pendanaan adalah kebijakan leverage. Leverage merupakan suatu perbandingan yang mencerminkan besarnya utang yang digunakan untuk pembiayaan oleh perusahaan dalam menjalankan aktivitas operasinya (Praditasari, 2017). Semakin besar penggunaan utang oleh perusahaan, maka semakin banyak jumlah beban bunga yang dikeluarkan oleh perusahaan, sehingga dapat mengurangi laba sebelum kena pajak perusahaan yang selanjutnya akan dapat mengurangi besaran pajak yang nantinya harus dibayarkan oleh perusahaan (Surbakti, 2012).

Shleifer dan Vishney (1986, dalam Khurana dan Moser, 2009) menyatakan bahwa kepemilikan institusional yang ada di dalam perusahaan akan memainkan peran penting di dalam pemantauan, mendisiplinkan dan mempengaruhi manajer. Kepemilikan institusional umumnya bertindak sebagai pihak yang memonitor perusahaan. Kepemilikan institusional adalah kepemilikan saham perusahaan yang dimiliki oleh institusi atau lembaga seperti perusahaan asuransi, bank, perusahaan investasi dan kepemilikan institusi lain (Permanasari, 2010). Adanya kepemilikan institusional dalam suatu perusahaan akan mendorong peningkatan pengawasan agar 
lebih optimal terhadap kinerja manajemen. Berdasarkan sudut pandang hubungan keagenan, akan terjadi kecenderungan bahwa manajemen akan mengelola perusahaan demi kepentingan dirinya sendiri tanpa memperhatikan kesejahteraan pemilik perusahaan atau pemegang saham. Di dalam praktiknya kepemilikan institusional memiliki fungsi monitoring yang lebih efektif dibandingkan dengan kepemilikan manajerial. Menurut penelitian yang dilakukan Khurana (2009) menyatakan besar kecilnya konsentrasi kepemilikan institusional maka akan mempengaruhi kebijakan tindakan meminimalkan beban pajak oleh perusahaan.

Penelitian ini dilakukan pada perusahaan manufaktur yang terdaftar di Bursa Efek Indonesia (BEI) dari tahun 2012-2016. Alasan pemilihan perusahaan manufaktur sebagai objek penelitian didasarkan pada beberapa hal, diantaranya: (1) perusahaan manufaktur merupakan salah satu sektor yang berkontribusi besar pada penerimaan pajak negara selain sektor pertambangan, keuangan, dan perkebunan, serta (2) perusahaan manufaktur sebagai suatu perusahaan yang telah menjadi wajib pajak yang difokuskan dalam daftar pemeriksaan Direktorat Jendral Pajak (Mulyani, 2014).

Tujuan dalam penelitian ini adalah untuk mendapatkan bukti empiris dan pembahasan mengenai pengaruh profitabilitas pada tax avoidance pada perusahaan manufaktur yang terdaftar di Bursa Efek Indonesia tahun 2012-2016, untuk mendapatkan bukti empiris dan pembahasan mengenai pengaruh leverage pada tax avoidance pada perusahaan manufaktur yang terdaftar di Bursa Efek Indonesia tahun 
ISSN: 2302-8556

E-Jurnal Akuntansi Universitas Udayana

Vol.22.3. Maret (2018): 2088-2116

2012-2016 dan untuk mendapatkan bukti empiris dan pembahasan mengenai pengaruh kepemilikan institusional pada tax avoidance pada perusahaan manufaktur yang terdaftar di Bursa Efek Indonesia tahun 2012-2016.

Adapun kegunaan yang diharapkan dapat diperoleh melalui pelaksanaan penelitian ini adalah kegunaan teoritis sebagai pendukung teoritis atau menambah khasanah ilmu pengetahuan mengenai penghindaran pajak (tax avoidance). Terjadinya tax avoidance dipengaruhi oleh adanya teori agensi. Terjadinya tax avoidance dipengaruhi oleh konflik kepentingan antara prinsipal dengan agen, sehingga masing-masing pihak akan berusaha untuk mengoptimalkan kepentingan pribadinya.

Teori agensi diharapkan mampu menjawab dan menjelaskan pengaruh profitabilitas, leverage, dan kepemilikan institusional pada penghindaran pajak pada perusahaan manufaktur yang terdaftar di Bursa Efek Indonesia tahun 2012-2016. Selain itu, diharapkan dapat dijadikan perbandingan, pengembangan, dan penyempurnaan dari penelitian-penelitian yang telah dilakukan sebelumnya serta sebagai referensi untuk penelitian-penelitian di masa yang akan datang mengenai penghindaran pajak sedangkan kegunaan praktis diharapkan dapat memberikan informasi yang dapat dijadikan pertimbangan bagi investor, kreditur, dan pemerintah ketika akan mengambil keputusan investasi. Serta hasil penelitian ini diharapkan dapat menjadi bahan referensi serta bahan pertimbangan bagi peneliti selanjutnya khususnya penelitian mengenai praktik penghindaran pajak (tax avoidance). 
Teori agensi menjelaskan hal yang dapat memacu para agent untuk meningkatkan laba perusahaan. Profitabilitas menggambarkan kemampuan perusahaan dalam mendapatkan laba melalui semua kemampuan sumber daya yang ada seperti kegiatan penjualan, kas, modal, jumlah karyawan, jumlah cabang, dan sebagainya (Harahap, 2008). Salah satu rasio yang digunakan untuk mengukur profitabilitas adalah Return On Asset (ROA). ROA berkaitan dengan laba bersih dan pengenaan pajak penghasilan untuk perusahaan. Semakin tinggi ROA maka semakin tinggi pula profitabilitasnya. Ketika laba yang diperoleh meningkat, maka jumlah pajak penghasilan akan meningkat sesuai dengan peningkatan laba perusahaan. Perusahaan yang memiliki profitabilitas tinggi memiliki kesempatan untuk memposisikan diri dalam tax planning yang dapat mengurangi jumlah beban kewajiban perpajakan (Chen et al. 2010). Perusahaan yang memiliki perencanaan pajak yang baik maka akan memperoleh pajak yang optimal, hal tersebut berakibat kecenderungan perusahaan untuk melakukan penghindaran pajak akan menurun (Prakosa, 2014). Penelitian yang dilakukan oleh Maharani (2014) menyatakan bahwa profitabilitas berpengaruh negatif terhadap penghindaran pajak.

$\mathrm{H}_{1}$ : Profitabilitas berpengaruh negatif terhadap tax avoidance.

Teori trade off menyatakan bahwa pendanaan keuangan oleh perusahaan yang berasal dari penggunaan hutang dapat memberi manfaat sebagai pengurang beban pajak. Kebijakan keputusan pendanaan yang ditetapkan oleh perusahaan dapat digambarkan melalui rasio leverage yang dimiliki perusahaan. Semakin tinggi 
ISSN: 2302-8556

E-Jurnal Akuntansi Universitas Udayana

Vol.22.3. Maret (2018): 2088-2116

leverage suatu perusahaan maka menunjukkan semakin tinggi ketergantungan perusahaan tersebut untuk membiayai asetnya dari pinjaman atau hutang. Hutang bagi perusahaan memiliki beban tetap yang berupa beban bunga. Beban bunga termasuk ke dalam beban yang yang dapat mengurangi penghasilan kena pajak (deductible expense) sehingga penggunaan hutang akan memberikan hubungan positif terhadap aktivitas penghindaran pajak oleh suatu perusahaan. Penelitian terkait leverage pernah dilakukan oleh Fadilla Rachmitasari (2015) yang menemukan bahwa leverage berpengaruh positif terhadap penghindaran pajak.

$\mathrm{H}_{2}$ : Leverage berpengaruh positif pada tax avoidance.

Teori agensi menyatakan bahwa adanya konflik kepentingan antara pemegang saham dan manajer. Dimana manajer ingin menghasilkan keuntungan sebanyakbanyaknya sedangkan pemegang saham ingin kesejahteraannya terjamin. Kepemilikan institusional merupakan kepemilikan saham yang dimiliki oleh perusahaan yang terdiri dari lembaga atau institusi seperti bank, perusahaan asuransi, perusahaan investasi dan kepemilikan institusi lainnya (Permanasari, 2010). Kepemilikan institusional berperan penting dalam mengawasi kinerja manajemen yang lebih optimal karena dianggap mampu memonitor setiap keputusan yang diambil oleh para manajer secara efektif dan dapat memaksa manajer untuk lebih berhati-hati dalam mengambil keputusan yang opurtunistik. Dalam penelitian yang dilakukan Merslythalia dan Lasmana (2016) menunjukkan bahwa kepemilikan institusional berpengaruh negatif terhadap penghindaran pajak. 
$\mathrm{H}_{3}$ : Kepemilikan institusional berpengaruh negatif pada tax avoidance.

\section{METODE PENELITIAN}

Penelitian ini merupakan penelitian kuantitatif dengan bentuk asosiatif. Penelitian berbentuk asosiatif merupakan penelitian yang menyelidiki hubungan antara variabel independen dan dependen. Pada penelitian ini, peneliti meneliti pengaruh profitabilitas, leverage, dan kepemilikan institusional pada tax avoidance.

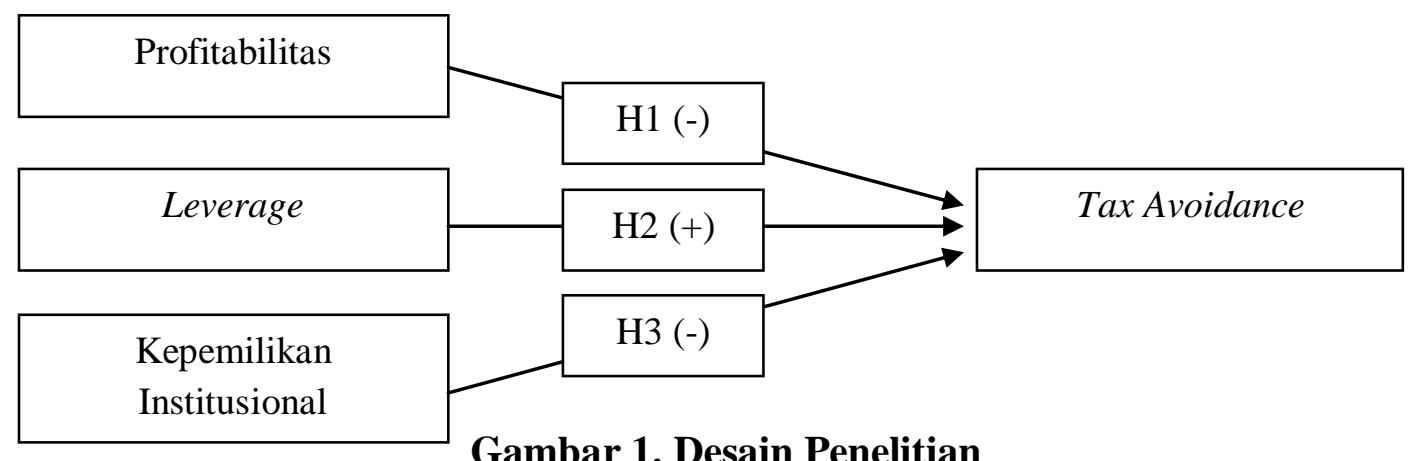

Sumber: Data diolah, 2017

Pada penelitian ini peneliti memilih lokasi penelitian pada perusahaan manufaktur yang terdaftar di Bursa Efek Indonesia (BEI) tahun 2012-2016 yang diunduh melalui web resmi BEI yaitu www.idx.co.id. Objek penelitian merupakan suatu atribut atau sifat atau nilai dari orang, objek atau kegiatan yang mempunyai variasi tertentu yang ditetapkan oleh peneliti untuk di pelajari dan kemudian ditarik kesimpulannya (Sugiyono, 2013). Objek pada penelitian ini adalah tax avoidance, 
ISSN: 2302-8556

E-Jurnal Akuntansi Universitas Udayana

Vol.22.3. Maret (2018): 2088-2116

profitabilitas, leverage, dan kepemilikan institusional perusahaan pada perusahaan manufaktur yang terdaftar di Bursa Efek Indonesia dari tahun 2012-2016.

Variabel penelitian adalah segala sesuatu yang berbentuk apa saja yang ditetapkan oleh peneliti untuk dipelajari sehingga diperoleh informasi tentang hal tersebut, kemudian ditarik kesimpulannya (Sugiyono, 2015). Dalam penelitian ini digunakan dua jenis variabel, yaitu variabel bebas (independen) dimana menurut Sugiyono (2015) merupakan variabel yang mempengaruhi atau yang menjadi sebab perubahannya atau timbulnya variabel dependen (terikat). Variabel bebas yang digunakan dalam penelitian ini adalah profitabilitas $\left(\mathrm{X}_{1}\right)$, leverage $\left(\mathrm{X}_{2}\right)$, dan kepemilikan institusional $\left(\mathrm{X}_{3}\right)$ sedangkan variabel terikat (dependen) dimana menurut Sugiyono (2012) merupakan variabel yang dipengaruhi atau yang menjadi akibat, karena adanya variabel bebas. Variabel terikat yang digunakan dalam penelitian ini adalah tax avoidance (Y).

Populasi adalah keseluruhan dari subjek penelitian (Arikunto, 2013). Populasi yang digunakan dalam penelitian ini adalah perusahaan manufaktur yang terdaftar di Bursa Efek Indonesia (BEI) periode tahun 2012-2016 yang berjumlah 157 perusahaan yang terbagi dalam 3 sektor perusahaan. Sektor industri dasar dan kimia sebanyak 68 perusahaan, sektor aneka industri sebanyak 44 perusahaan, dan sektor industri barang konsumsi sebanyak 43 perusahaan.

Dalam penelitian ini, sampel ditentukan dengan metode purposive sampling dengan menggunakan kriteria-kriteria yang telah ditentukan. Sampel yang dipilih oleh 
peneliti adalah perusahaan yang menyajikan data yang dibutuhkan dalam penelitian ini, yaitu biaya pajak, total laba sebelum pajak, total laba bersih, total aset, total liabilitas, dan kepemilikan institusional. Adapun kriteria-kriteria ditentukan berdasarkan tujuan atau masalah penelitian, yaitu perusahaan manufaktur yang terdaftar di Bursa Efek Indonesia (BEI) selama periode 2012-2016, laporan tahunan perusahaan menggunakan mata uang rupiah dalam pelaporan unit moneternya dan telah diaudit, perusahaan yang memiliki data lengkap sesuai dengan tujuan penelitian, perusahaan yang menerbitkan laporan keuangan untuk periode yang berakhir pada tanggal 31 Desember dan tidak mengalami kerugian selama periode pengamatan dan perusahaan dengan nilai Cash Effective Tax Rate (CETR) kurang dari satu, agar tidak membuat masalah dalam estimasi model (Gupta dan Newberry, 1997).

Metode pengumpulan data yang digunakan dalam penelitian ini adalah metode observasi nonpartisipan. Metode observasi nonpartisipan yaitu teknik pengumpulan data dengan cara membaca, mengamati, mencatat, dan mempelajari uraian-uraian dari dokumen yang berhubungan dengan penelitian (Sugiyono, 2014). Observasi ini dilakukan dengan memperoleh data laporan keuangan perusahaan manufaktur yang telah terdaftar di Bursa Efek Indonesia (BEI) mulai dari tahun 20122016 sesuai dengan kriteria pemilihan sampel.

Jenis data yang digunakan dalam penelitian ini adalah data kuantitatif. Data kuantitatif merupakan data dalam bentuk angka-angka atau data kualitatif yang diangkakan (Sugiyono, 2014). Data kuantitatif dalam penelitian ini adalah tax 
ISSN: 2302-8556

E-Jurnal Akuntansi Universitas Udayana

Vol.22.3. Maret (2018): 2088-2116

avoidance, profitabilitas, laverage, dan kepemilikan institusional pada perusahaan manufaktur yang terdaftar di Bursa Efek Indonesia (BEI) periode 2012-2016 sedangkan sumber data yang digunakan dalam penelitian ini adalah data sekunder. Data sekunder adalah sumber data yang tidak langsung memberikan data kepada pengumpul data, seperti dapat melalui perantara orang lain atau dokumen (Sugiyono, 2014). Data sekunder dalam penelitian ini yaitu laporan keuangan yang diperoleh dari perusahaan manufaktur yang terdaftar di Bursa Efek Indonesia (BEI).

Pengujian hipotesis pada penelitian ini menggunakan metode analisis regresi linear berganda. Regresi ini digunakan untuk mengukur nilai Y dan seberapa besar pengaruh profitabilitas, leverage, dan kepemilikan institusional terhadap praktik penghindaran pajak (tax avoidance). Adapun model regresi dari penelitian ini adalah sebagai berikut:

CETR $=\alpha+\beta_{1}$ ROA $+\beta_{2}$ LEV $+\beta_{3}$ INSTI $+\varepsilon$

Keterangan :

CETR = Cash Effective Tax Rate

ROA $=$ Profitabilitas

LEV = Leverage

INSTI $=$ Kepemilikan Institusional

$\alpha \quad=$ Kontansta

$\varepsilon \quad=$ error

$\beta_{1-3}=$ nilai koefisien variabel dari setiap variabel $\mathrm{X}$

\section{HASIL DAN PEMBAHASAN}

Model regresi yang baik mengharuskan data yang digunakan berdistribusi normal. Pengujian normalitas dalam penelitian ini menggunakan statistik KolmogrovSmirnov. Apabila nilai signifikansi $>0,05$ berarti data residual berdistribusi normal, 
sedangkan apabila nilai signifikansi $<0,05$ berarti data residual tidak berdistribusi normal (Ghozali, 2011). . Hasil uji Kolmogorov-Smirnov dapat dilihat pada Tabel 1. yaitu sebagai berikut. Berdasarkan hasil uji normalitas maka dapat disimpulkan bahwa data penelitian yang digunakan dalam penelitian ini berdistribusi normal. Hal ini ditunjukkan dengan nilai Sig (2-tailed) sebesar 0,406 lebih besar dari tingkat signifikansi sebesar 0,05 .

Uji multikolinearitas bertujuan untuk mengetahui apakah ada korelasi antar variabel bebas dalam penelitian ini. Model regresi yang baik seharusnya tidak terjadi korelasi diantara variabel bebas. Model regresi yang bebas dari multikolinearitas adalah memiliki tolerance variabel bebas yang lebih dari $10 \%$ atau 0,1 atau sama dengan nilai Variance Inflation Factor (VIF) kurang dari 10. Hasil uji multikolinearitas disajikan pada Tabel 2 berikut.

Pada uji multikolinearitas diketahui bahwa masing-masing variabel bebas memiliki nilai tolerance lebih besar dari 0,1 dan VIF lebih kecil dari 10, sehingga dapat disimpulkan bahwa variabel bebas yang digunakan dalam penelitian ini tidak saling berkolerasi secara signifikan. Hasil pengujian ini menunjukkan bahwa data yang dianalisis memenuhi asumsi multikolinaritas.

Uji autokorelasi digunakan untuk menguji apakah dalam model regresi terdapat korelasi antara kesalahan pengganggu pada periode t dengan kesalahan. Untuk mendeteksi ada atau tidaknya autokorelasi dapat digunakan dengan uji Durbin Watson (D-W), dimana kriteria pengujian menggunakan Durbin Watson dengan 
ISSN: 2302-8556

E-Jurnal Akuntansi Universitas Udayana

Vol.22.3. Maret (2018): 2088-2116

angka antara $-2<\mathrm{d}<2$ (Santoso, 2010:213), dengan rincian: (1) Angka D-W dibawah 2 berarti terdapat autokorelasi positif. (2) Angka D-W diantara -2 sampai +2 berarti tidak ada autokorelasi. (3) Angka D-W diatas +2 berarti ada autokorelasi negatif. Uji autokorelasi menunjukkan bahwa nilai uji Durbin Watson pada penelitian ini berkisar antara -2 sampai dengan +2 yaitu berada pada nilai 1,570 . Jadi dapat disimpulkan bahwa koefisien regresi bebas gangguan autokorelasi.

Pengujian ini bertujuan untuk mengetahui apakah dalam model regresi yang digunakan terjadi ketidaksamaan varian dari residual suatu pengamatan ke pengamatan yang lain (Ghozali, 2009). Model regresi yang baik adalah yang tidak mengandung gejala heteroskedastisitas atau mempunyai varians yang homogen. Uji heteroskedastisitas dalam penelitian ini dilakukan dengan uji Glesjer. Jika signifikansi t dari hasil regresi nilai absolute residual terhadap variabel bebas lebih dari 0,05 maka model regresi tidak mengandung heteroskedastisitas. Pada Tabel 5 disajikan hasil uji heteroskedastisitas dengan uji Glesjer. Berdasarkan Uji heteroskedastisitas dapat dilihat bahwa nilai signifikansi masing-masing variabel untuk uji heteroskedastisitas berada diatas 0,05. Hasil pengujian tersebut menunjukkan bahwa model regresi yang digunakan terbebas dari asumsi heteroskedastisitas.

Berdasarkan uji asumsi klasik, diketahui bahwa data dalam penelitian ini terdistribusi dengan normal, tidak ada autokorelasi, bebas dari multikolinearitas, serta 
tidak terjadi heteroskedastisitas sehingga data yang tersedia telah memenuhi syarat untuk menggunakan model regresi linear berganda dengan hasil sebagai berikut:

\begin{tabular}{|c|c|c|c|c|c|c|}
\hline & & ji Anali & $\begin{array}{l}\text { Tabel } \\
\text { Regre }\end{array}$ & Linear Berg & & \\
\hline & \multirow{2}{*}{ Model } & \multicolumn{2}{|c|}{$\begin{array}{l}\text { Unstandardized } \\
\text { Coefficients }\end{array}$} & \multirow{2}{*}{$\begin{array}{c}\begin{array}{c}\text { Standardized } \\
\text { Coefficients }\end{array} \\
\text { Beta }\end{array}$} & \multirow{2}{*}{$\mathbf{T}$} & \multirow{2}{*}{ Sig. } \\
\hline & & B & $\begin{array}{l}\text { Std. } \\
\text { Error }\end{array}$ & & & \\
\hline \multirow[t]{4}{*}{1} & (Constant) & 0,261 & 0,040 & & 6,582 & 0,000 \\
\hline & Profitabilitas & $-0,402$ & 0,103 & $-0,322$ & $-3,894$ & 0,000 \\
\hline & Leverage & 0,035 & 0,055 & 0,052 & 0,647 & 0,519 \\
\hline & $\begin{array}{l}\text { Kepemilikan } \\
\text { Institusional }\end{array}$ & 0,079 & 0,045 & 0,129 & 1,750 & 0,082 \\
\hline
\end{tabular}

Sumber : Data diolah, 2017

Berdasarkan Tabel 1. diatas maka diperoleh persamaan regresi sebagai berikut.

$Y=0,216-0,402 X_{1}+0,035 X_{2}+0,079 X_{3}+e$

Persamaan di atas menunjukkan bahwa nilai konstanta yang bernilai 0,216 mempunyai arti jika semua variabel bebas yaitu profitabilitas, leverage, dan kepemilikan institusional dalam keadaan konstan, maka akan mengakibatkan nilai dari penghindaran pajak adalah sebesar 0,216. Koefisien profitabilitas sebesar 0,402 memiliki arti bahwa apabila profitabilitas meningkat $1 \%$ maka akan menyebabkan penghindaran pajak menurun sebesar 0,402 dengan asumsi faktor lain konstan. Koefisien leverage sebesar 0,035 memiliki arti bahwa apabila leverage meningkat $1 \%$ menyebabkan penghindaran pajak meningkat sebesar 0,035 dengan asumsi faktor lainnya konstan. Koefisien kepemilikan institusional sebesar 0,079 memiliki arti 
ISSN: 2302-8556

E-Jurnal Akuntansi Universitas Udayana

Vol.22.3. Maret (2018): 2088-2116

bahwa apabila kepemilikan institusional meningkat 1 satuan maka akan menyebabkan penghindaran pajak meningkat sebesar 0,079 dengan asumsi faktor lain konstan.

Uji koefisien determinasi mampu menunjukkan seberapa besar variabel independen dapat menjelaskan variabel dependen Pada penelitian ini koefisien determinasi (Adjusted $R^{2}$ ) variabel bebas dalam model penelitian dapat dilihat pada Tabel 7 berikut.

Tabel 2.

Hasil Uji Koefisien Determinasi

\begin{tabular}{|c|c|c|c|c|c|}
\hline Model & $\mathbf{R}$ & R Square & $\begin{array}{l}\text { Adjusted R } \\
\text { Square }\end{array}$ & $\begin{array}{l}\text { Std. Error of the } \\
\text { Estimate }\end{array}$ & $\begin{array}{l}\text { Durbin- } \\
\text { Watson }\end{array}$ \\
\hline 1 & $0,340^{\mathrm{a}}$ & 0,116 & 0,100 & 0,09758683 & 1,570 \\
\hline
\end{tabular}

Sumber: Data diolah, 2017

Pada Tabel 2. dapat dilihat bahwa angka koefisien determinasi yang dilihat melalui adjusted $\mathrm{R}$ square yaitu sebesar 0,100 . Hal ini berarti bahwa sebesar $10 \%$ variasi penghindaran pajak dapat dijelaskan oleh variasi variabel bebas yaitu profitabilitas, leverage, dan kepemilikan institusional. Sedangkan 90\% sisanya dijelaskan oleh variabel lain di luar penelitian.

Uji kelayakan model atau biasa disebut uji $\mathrm{F}$ mampu menunjukkan apakah semua variabel independen yang dimasukkan dalam model mempunyai pengaruh secara bersama-sama terhadap variabel dependen. Hasil pengujian model dapat dilihat dari hasil analisis regresi pada Tabel 3. berikut.

Tabel 3.

Hasil Uji Kelayakan Model (Uji F) 


\begin{tabular}{llrrrrr}
\hline & Model & Sum of Squares & Df & Mean Square & F & Sig. \\
\hline 1 & Regression & 0,217 & 3 & 0,072 & 7,592 & $0,000^{\mathrm{a}}$ \\
& Residual & 1,657 & 174 & 0,010 & & \\
& & 1,874 & 177 & & & \\
& Total & & & & & \\
& & & & &
\end{tabular}

Sumber : Data diolah, 2017

Pada Tabel 3. dapat dilihat bahwa nilai signifikasnsi dari uji $\mathrm{F}$ adalah sebesar 0,000 lebih kecil dari 0,05 maka dapat dikatakan model yang digunakan layak untuk menguji variabel independen terhadap variabel dependen.

Profitabilitas pada penelitian ini menunjukkan bahwa berpengaruh negatif signifikan pada tax avoidance. Semakin tinggi profitabilitas perusahaan maka semakin menekan tindakan tax avoidance. Slemrod (1989) mengatakan bahwa perusahaan yang mempunyai profitabilitas tinggi cenderung akan melaporkan pajaknya dengan jujur dari pada perusahaan dengan profitabilitas yang rendah. Perusahaan dengan profitabilitas rendah pada umumnya mengalami kesulitan keuangan (financial difficulty) dan cenderung akan melakukan ketidakpatuhan pajak. Perusahaan yang memiliki profitabilitas tinggi memiliki kesempatan untuk memposisikan diri dalam tax planning yang dapat mengurangi jumlah beban kewajiban perpajakan (Chen et al. 2010). Perusahaan yang memiliki perencanaan pajak yang baik maka akan memperoleh pajak yang optimal, hal tersebut berakibat kecenderungan perusahaan untuk melakukan penghindaran pajak akan menurun (Prakosa, 2014). Hasil penelitian ini mendukung penelitian yang telah dilakukan oleh 
ISSN: 2302-8556

E-Jurnal Akuntansi Universitas Udayana

Vol.22.3. Maret (2018): 2088-2116

Maharani dan Alit (2016) serta Kurniasih dan Sari (2017) dimana mereka menyatakan bahwa profitabilitas berpengaruh negatif pada tax avoidance.

Leverage pada penelitian ini menunjukkan bahwa tidak berpengaruh signifikan pada tax avoidance. Semakin tinggi tingkat hutang suatu perusahaan, maka tidak akan mempengaruhi adanya praktik tax avoidance. Hal tersebut terjadi dikarenakan semakin tinggi tingkat hutang suatu perusahaan maka pihak manajemen akan lebih konservatif dalam melakukan pelaporan keuangan atau operasional perusahaan. Pihak manajemen akan lebih berhati-hati dan tidak akan mengambil resiko yang tinggi untuk melakukan aktivitas penghindaran pajak guna menekan beban pajaknya. Apabila hutang digunakan dalam jumlah yang besar maka dapat menimbulkan kerugian bagi perusahaan.

Menurut Ramlall dalam Margaretha dan Ramadhan (2010) menyatakan bahwa struktur modal yang optimal terjadi apabila interest tax shield seimbang dengan leverage related cost seperti financial distress dan bankruptcy. Untuk menghindari pembiayaan yang berasal dari $100 \%$ hutang maka diperhitungkan juga biaya hutang atau financial distress yang disebut juga cost of bankcruptcy yang menyebabkan perusahaan tidak dapat mencapai keuntungan optimal dari pembiayaan $100 \%$ hutang. Perusahaan dengan tingkat leverage yang tinggi memiliki beban bungan yang tinggi serta resiko yang tinggi pula, sehingga jika banyak menggunakan hutang dari pihak luar perusahaan laba perusahaan menjadi tidak optimal. Hasil 
penelitian ini sejalan dengan Darmawan (2014), Dewinta (2016), dan Moses (2017) yang menyatakan bahwa leverage tidak berpengaruh terhadap penghindaran pajak.

Kepemilikan institusional pada penelitian ini menunjukkan bahwa tidak berpengaruh signifikan pada penghindaran pajak. Keberadan struktur kepemilikan institusional tersebut mengindikasikan adanya tekanan dari pihak institusional kepada manajemen perusahaan untuk melakukan kebijakan pajak agresif untuk memaksimalkan perolehan laba untuk investor institusional. Perusahaan memiliki tanggung jawab kepada pemegang saham, maka pemilik instusional memiliki insentif untuk memastikan bahwa manajemen perusahaan membuat keputusan yang akan memaksimalkan kesejahteraan pemegang saham. Pada pengungkapan suka rela menemukan bahwa perusahaan dengan kepemilikan institusional yang lebih besar lebih memungkinkan untuk mengeluarkan, meramalkan dan memperkirakan sesuatu lebih spesifik, akurat dan optimis (Khurana ,2009).

Menurut Jasen dan Meckling (1976) dalam Sujoko (2006) memaparkan bahwa hasil temuan penelitian ini tidak mendukung agency theory, karena berdasarkan agency theory terdapat pemisahan antara pemilik dengan pengelola, akan tetapi hasil penelitian menunjukkan peranan pendiri perusahaan sangat dominan dalam menentukan kebijakan perusahaan. Kepemilikan institusional yang bertindak sebagai pihak yang memonitor perusahaan belum tentu mampu memberikan kontrol yang baik terhadap tindakan manajemen atas oportunistiknya dalam melakukan praktik tax avoidance. Hal ini dapat disebabkan oleh kualitas sumber daya dari 
ISSN: 2302-8556

E-Jurnal Akuntansi Universitas Udayana

Vol.22.3. Maret (2018): 2088-2116

pemilik institusional yang masih kurang. Pemegang saham institusi tidak menjalankan wewenangnya dengan benar dalam mengawasi serta mengontrol keputusan yang diambil oleh manajer sehingga tax avoidance tetap terjadi.

\section{SIMPULAN}

Berdasarkan hasil penelitian yang diperoleh melalui pengujian statistik serta pembahasan seperti yang telah diuraikan pada bab sebelumnya, maka dapat disimpulkan bahwa, profitabilitas berpengaruh negatif signifikan pada tax avoidance, hal ini dikarenakan semakin profitable perusahaan maka perusahaan tersebut dapat memposisikan diri dalam tax planning sehingga mampu memperoleh pajak yang optimal, leverage tidak berpengaruh signifikan pada tax avoidance, hal ini disebabkan karena perusahaan dengan tingkat leverage yang tinggi memiliki beban bungan yang tinggi serta resiko yang tinggi pula, sehingga jika banyak menggunakan hutang dari pihak luar perusahaan laba perusahaan menjadi tidak optimal dan kepemilikan institusional tidak berpengaruh signifikan pada tax avoidance, hal ini disebabkan oleh kurangnya kualitas sumber daya dari pemilik institusional sehingga mereka tidak mampu melakukan pengawasan dan kontrol dengan benar terhadap keputusan yang diambil oleh manajer.

Berdasarkan hasil penelitian dan simpulan di atas, maka saran yang dapat diberikan adalah sebagai berikut bagi peneliti selanjutnya hendaknya memperluas objek atau sampel penelitian sehingga dapat meningkatkan generalisasi hasil. Selain itu nilai adjusted $R^{2}$ dalam penelitian ini hanya sebesar $10,00 \%$ menunjukkan bahwa 
masih banyak faktor lain yang berpengaruh pada tax avoidance namun belum diuji dalam penelitian ini. Peneliti selanjutnya hendaknya menambahkan faktor lain seperti kepemilikan manajerial, ukuran perusahaan,, corporate governance, atau variabel lainnya. Bagi perusahaan diharapkan lebih berhati-hati dalam menggunaan hutang untuk membiayai kegiatan operasionalnya supaya tidak menimbulkan resiko yang terlalu tinggi bagi kelangsungan perusahaan. Bagi investor khususnya pemilik saham institusional diharapkan lebih meningkatkan pengawasan serta kontrol terhadap keputusan atau kebijakan yang diambil oleh perusahaan agar manajer tidak melakukan tindakan oportunitis yang menyebabkan kerugian bagi perusahaan maupun pemegang saham.

\section{REFERENSI}

Agusti, W. Y. (2014). Pengaruh Profitabilitas, Leverage, Dan Corporate Governance Terhadap Tax Avoidance (Studi Empiris Pada Perusahaan Manufaktur yang Terdaftar di BEI tahun 2009-2012). Jurnal Akuntansi, 2(3).

Annisa, N. A., dan L. Kurniasih. (2012). Pengaruh Corporate Governance Terhadap Tax Avoidance. Jurnal Akuntansi \& Auditing, Volume 8, No. 2, 95-189.

Ardyansah, D. (2014). Pengaruh Size, Leverage, Profitability, Capital Intensity Ratio dan Komisaris Independen Terhadap Effective Tax Rate (ETR) (Studi Empiris pada Perusahaan Manufaktur yang Terdaftar Di BEI Selama Periode 2010-2012). Doctoral dissertation, Fakultas Ekonomika dan Bisnis.

Arikunto, S. (2013). Prosedur Penelitian: Suatu Pendekatan Praktik. Jakarta: Rineka Cipta.

Boediono, Gideon. (2005). Kualitas Laba: Studi Pengaruh Mekanisme Corporate Governance dan Dampak Manajemen Laba dengan Menggunakan Analisis Jalur. Jurnal. Simposium Nasional Akuntansi (SNA) VIII Solo. 
ISSN: 2302-8556

E-Jurnal Akuntansi Universitas Udayana

Vol.22.3. Maret (2018): 2088-2116

Bovi, Maurizio. (2005). Book-Tax Gap. An Income Horse Race. Working Paper $n$. 61.

Brealey, R. A. \& Myers, S. C. (1991). Principles of Corporate Finance, 4th edition. McGraw Hill Inc.

Chen, S., Chen, X., Cheng, Q., Shevlin, T. (2010). Are Family Firms More Tax Aggressive Than Non-Family Firms? Journal of Financial Economics. 95, 41 61

Darmawan, I. G. H., \& Sukartha, I. M. (2014). Pengaruh Penerapan Corporate Governance, Leverage, Return On Assets, dan Ukuran Perusahaan pada Penghindaran Pajak. E-Jurnal Akuntansi Universitas Udayana 9.1.

Desai, M. A., \& Dharmapala, D. (2006). Corporate Tax Avoidance and HighPowered Incentives. Journal of Financial Economics, 79(1), 145-179

Dewi, K dan I. K Jati. (2014). Pengaruh Karakter Eksekutif, Karateristik Perusahaan, dan Corporate Governance pada Tax Avoidance di Bursa Efek Indonesia. EJurnal Akuntansi ISSN 2302-8556 6.2: 249- 260.

Dewi, S. P. (2012). Pengaruh Pengendalian Internal dan Gaya Kepemimpinan Terhadap Kinerja Karyawan SPBU Yogyakarta (Studi Kasus Pada SPBU Anak Cabang Perusahaan RB. Group). Nominal: Barometer Riset Akuntansi dan Manajemen, 1(1).

Dewinta, I. A. R. (2015). Pengaruh Ukuran Perusahaan, Umur Perusahaan, Profitabilitas, Leverage, dan Pertumbuhan Penjualan Terhadap Tax Avoidance (Studi pada Perusahaan Manufaktur di Bursa Efek Indonesia). Skripsi. Universitas Udayana

Dharma, I. M. S., \& Dharma, I. M. S. (2015). Pengaruh Leverage, Intensitas Aset Tetap, Ukuran Perusahaan, dan Koneksi Politik Terhadap Penghindaran Pajak. Doctoral dissertation, Universitas Udayana.

Diantari, P. R., \& Ulupui, I. G. K. (2016). Pengaruh Komite Audit, Proporsi Komisaris Independen, dan Proporsi Kepemilikan Institusional Terhadap Tax Avoidance. E-Jurnal Akuntansi, 16(1), 702-732.

Dyreng, Scott, Michelle H, dan Edward L.M. (2008). Long Run Corporate Tax Avoidance. The Accounting Review 83. pp. 61-82.

Fadhilah, R. (2014). Pengaruh Good Corpotare Governance Terhadap Tax Avoidance. Jurnal Akuntansi. Universitas Negeri Padang, 1 (1), 1-22. 
Friese, A, S. Link dan S. Mayer. (2006). Taxation and Corporate Governance. Working Paper

Ghozali, I. (2009). Aplikasi Analisis Multivariate Dengan Program SPSS, Edisi Keempat, Penerbit Universitas Diponegoro.

Ghozali, I. (2016). Aplikasi Analisis Multivariate. Badan Penerbit Universitas Diponegoro: Semarang

Gupta, S., and K. Newberry. (1997). Determinants of the variability on corporate effective tax rates: Evidence from longitudinal data. Journal of Accounting and Public Policy, 16 (1), 1-34.

Halim, A. dan Mamduh M. H. (2009). Analisis Laporan Keuangan. Edisi 4. UPP STIM YKPN. Yogyakarta.

Hanlon, M. dan S. Heitzman. (2010). A Review Of Tax Research. Journal of Accounting and Economics. 50: h:127-178

Harahap, S. S. (2008). Analisis Kritis Atas Laporan Keuangan. Raja Grafindo Persada, Jakarta.

Husnan, S. (2001). Dasar-Dasar Teori Portofolio dan Analisis Sekuritas. Yogyakarta. Penerbit : UPP AMP YKPN

Ifanda, B. A.. (2016). Analisis Pengaruh Profitabilitas, Leverage, dan Kompensasi Rugi Fiskal Terhadap Tax Avoidance. Journal Accounting Unila.

Istijanto, (2009). Aplikasi Praktis Riset Pemasaran, Jakarta: Gramedia Pustaka Utama

Jensen, M. C and Meckling, W.H. (1976). Theory of the Firm : Managerial Behavior, Agency Costs and Ownership Structure . Journal of Financial Economics. Oktober, 1976, V. 3, No. 4, pp. 305-360. http://papers.ssrn.com

Kasmir. (2008). Analisis Laporan Keuangan. Jakarta: Rajawali Pers.

Khurana, I. K. dan W. J. Moser. (2009). Institusional Ownership and Tax Aggressiveves. www.ssrn.com

Lestari, M. I. dan T. Sugiharto. (2007). Kinerja Bank Devisa Dan Bank Non Devisa Dan Faktor-Faktor Yang Mempengaruhinya. Proceeding PESAT (Psikologi, Ekonomi, Sastra, Arsitek \& Sipil). 21-22 Agustus, Vol.2. Fakultas Ekonomi, Universitas Gunadarma. 
Lim, Y. D. (2011). Tax avoidance, cost of debt and shareholder activism: Evidence from Korea. Journal of Banking \& Finance 35, 456-470.

Maharani, I.G.A C., \& Suardana, K. A. (2014). Pengaruh Corporate Governance, Profitabilitas, dan Karakteristik Eksekutif pada Tax avoidance Perusahaan Manufaktur. E-Jurnal Akuntansi, 9(2), 525-539.

Mardiasmo. (2013). Perpajakan Edisi Revisi 2013. Yogyakarta: Penerbit Andi

Mella V, D. Pratomo, dan Kurnia. (2017). Pengaruh Kepemilikan Institusional dan Kepemilikan Manajerial dengan Variabel Kontrol Ukuran Perusahaan dan Leverage terhadap Penghindaran Pajak. Jurnal Managemen. Fakultas Ekonomi dan Bisnis Universitas Telkom.

Merks, P. (2007). Categorizing International Tax Planning. Fundamentals of International Tax Planning. IBFD: h:66-69

Merslythalia, D. R. dan M. S. Lasmana, (2016). Pengaruh Kompetensi Eksekutif, Ukuran Perusahaan, Komisaris Independen, Dan Kepemilikan Institusional Terhadap Tax Avoidance. Jurnal Ilmiah Akuntansi dan Bisnis, Vol.11, No. 2, Juli 2016.

Moses D. R. S. (2017). Pengaruh Profitabilitas, Leverage, dan Corporate Governance Terhadap Tax Avoidance. Jurnal Skripsi. Sekolah Tinggi Ilmu Ekonomi Indonesia.

Permanasari, W. I. (2010). Pengaruh Kepemilikan Manajemen, Kepemilikan Institusional dan Corporate Social Responsibility terhadap Nilai Perusahaan. Skripsi Universitas Diponegoro: Semarang.

Praditasari, A., \& Setiawan, P. E. (2017). Pengaruh Good Corporate Governance, Ukuran Perusahaan, Leverage dan Profitabilitas Pada Tax Avoidance. EJurnal Akuntansi, 19(2), 1229-1258.

Pradipta, D. H. (2015). Pengaruh Corporate Social Responsibility (CSR), Profitabilitas, Leverage, dan Komisaris Independen Terhadap Praktik Penghindaran Pajak . Doctoral dissertation, Universitas Gadjah Mada

Prakosa, K. B. (2014). Pengaruh Profitabilitas, Kepemilikan Keluarga, dan Corporate Governance terhadap Penghindaran Pajak di Indonesia. Simposium Nasional Akuntansi XVII. Mataram 
Pujiati. (2015). Pengaruh Kepemilikan Manajerial, Kepemilikan Institusional, dan Kesempatan Investasi Terhadap Kebijakan Dividen dengan Likuiditas Sebagai Variabel Pemoderasi. Jurnal. Yogyakarta: Universitas Negeri Yogyakarta

Rachmithasari, A. F. (2015). Pengaruh Return On Assets, Leverage, Corporate Governance, Ukuran Perusahaan dan Kompensasi Rugi Fiskal pada Tax Avoidance (Perusahaan Manufaktur yang Terdaftar di Bursa Efek Indonesia Tahun 2011-2013). Doctoral dissertation, Universitas Muhammadiyah Surakarta.

Republik Indonesia, Undang-Undang Nomor 36 Tahun 2008 Tentang Perubahan Keempat Atas Undang-Undang Nomor 7 Tahun 2983 Tentang Pajak Penghasilan

Republik Indonesia, Undang-Undang Nomor 16 tahun 2009 Tentang Ketentuan Umum dan Tata Cara Perpajakan

Richardson, Grant and R. Lanis. (2007). Determinants of Variability In Corporate Effective Tax Rates and Tax Reform: Evidence From Australia. Jorunal of Accounting and Public Policy 26 (2007) 689-704.

Santoso, I., Rahayu, N. (2013). Corporate Tax Management . Jakarta : Ortax

Santoso, S. (2014). Statistik Multivariat Edisi Revisi. Jakarta: PT Elex Media Komputindo.

Sari, G. M. (2014). Pengaruh Corporate Governance, Ukuran Perusahaan, Kompensasi Rugi Fiskal Dan Struktur Kepemilikan Terhadap Tax Avoidance (Studi Empiris Pada Perusahaan Manufaktur yang Terdaftar di BEI tahun 2008-2012). Jurnal Akuntansi, 2(3).

Sartori, N. (2010). Effect of Strategic Tax Behaviors on Corporate Governance. www.ssrn.com

Slemrod, J. (1989). Complexity, Compliance Cost, and Tax Evasion. An Agenda for Compliance Research, Vol. 2. Philadelphia: University of Pensylvania Press.

Suandy, E. (2008). Hukum Pajak. Edisi 4. Jakarta: Salemba Empat

Sugiyono. (2014) Metode Penelitian Kuantitatif Kualitatif dan R\&D. Bandung : Alfabeta. 
ISSN: 2302-8556

E-Jurnal Akuntansi Universitas Udayana

Vol.22.3. Maret (2018): 2088-2116

Soemitro, R. (1990). Asas dan Dasar Perpajakan 1, Cetakan keempat. Eresco. Bandung

Swingly, C., \& Sukartha, I. M. (2015). Pengaruh Karakter Eksekutif, Komite Audit, Ukuran Perusahaan, Leverage dan Sales Growth pada Tax Avoidance. EJurnal Akuntansi, 10(1), 47-62.

Tarjo. (2008). Pengaruh Konsentrasi Kepemilikan Institusional dan Leverage terhadap Manajemen Laba, Nilai Pemegang Saham, Serta Cost Of Equity Capital. Jurnal. Simposium Nasional Akuntansi XI. Pontianak

Utami, N. W. (2013). Pengaruh Struktur Corporate Governance, Size, Profitabilitas Perusahaan terhadap Tax Avoidance. Skripsi UNS.

Van Horne, James C., Jhon M. Wachowicsz. (2012). Prinsip-Prinsip Manajemen Keuangan (terjemahan). Jakarta. Salemba Empat

Walby, K. (2010). What is Difference Between Statutory, Average, Marginal, and Effective Tax Rate?. Journal

Yulfaida dan Zhulaikha, (2012). Pengaruh Size, Proftabilitas, Profile, Leverage Dan Ukuran Dewan Komisaris Terhadap Pengungkapan Tanggung Jawab Sosial Pada Perusahaan Manufaktur Di Bursa Efek Indonesia, Semarang: UNDIP, Diponegoro Journal Of Accounting 1(2), 2012, 